\title{
ENDORHIZAL FUNGAL ASSOCIATION AND COLONIZATION PATTERNS IN SOLANACEAE
}

\author{
ThangaVelu MuthukumaR ${ }^{1}$ \& Ramalingam Sathya
}

\begin{abstract}
The Solanaceae family includes plants of high economic and medicinal value. Information on endorhizal associations in Solanaceae is limited. We investigated arbuscular mycorrhizal (AM) and dark septate endophyte (DSE) fungal associations in 20 solanaceous plant species ( 7 genera) taken from one or more sites, measuring the percentage of root length colonized in plants having different AM and DSE fungal structures. Root samples of all the plant species examined had AM fungal structures, and DSE fungal colonization was found in $80 \%$ of the plant species. Total AM and DSE fungal colonization and root length of plants with different fungal structures varied significantly between species. Significant between-site variation was found for root length in plants with fungal structures in Lycopersicon esculentum Mill., Capsicum annuum L., Datura metel L., Solanum melongena L., S. nigrum L., S. trilobatum L. and S. torvum SW. AM morphology was predominantly intermediate-type (60\%), followed by Paris-type (30\%). Solanum melongena and S. nigrum at different sites had Paris-type or intermediate AM morphology. DSE fungal colonization also exhibited significant between-site variation in Capsicum frutescens, C. annum, Datura metel, Solanum melongena, S. trilobatum and S. nigrum. We found a significant negative correlation between AM and DSE fungal colonization.
\end{abstract}

Key words: arbuscular mycorrhiza, arbuscules, arbusculate coils, dark septate endophyte fungi, nightshade

Thangavelu Muthukumar \& Ramalingam Sathya, Root and Soil Biology Laboratory, Department of Botany, Bharathiar University, Coimbatore-641046,Tamilnadu,India; e-mail: tmkum@yahoo.com

\section{INTRODUCTION}

The plant family Solanaceae, commonly known as the nightshade or potato family, is a large family with 2678 species in 115 different genera (Anonymous 2013). Members of this family are distributed in temperate and tropical regions, with a large number occurring in Australia and Central and South America. Herbs are dominant in this family, with a few shrubs and trees. A number of important agricultural crops such as potatoes, tomatoes, aubergines and peppers belong to this family (Knapp et al. 2004). This family also contains many popular garden ornamental plants (e.g., Petunia Juss., Browallia L., Salpiglossis Ruiz \& Pav.) and is an important source of spices and medicinal plants. Solanaceous species are often rich in alkaloids. The toxicity of these alkaloids to humans and other animals can range from mild irritation to lethality even in small quantities (Chowański et al. 2016). The poisonous species in this family include

\footnotetext{
1 Corresponding author
}

Atropa belladonna L., Hyoscyamus niger L. and Datura stramonium L. The family includes an important economic plant, tobacco (Nicotiana tabacum L.), which contains highly toxic alkaloids such as anabasine, anatabine, nicotine and nornicotine (Sun et al. 2013).

Arbuscular mycorrhizal (AM) fungi belonging to the Glomeromycota are a major component of the soil microflora of terrestrial ecosystems and play a significant role in the structure and functioning of these ecosystems (Lee et al. 2013). These fungi benefit plants through the uptake of immobile or diffusion-limited mineral nutrients from the soil, such as phosphorus $(\mathrm{P})$, zinc $(\mathrm{Zn})$ and copper $(\mathrm{Cu})$, and more mobile elements such as sulfur (S), potassium $(\mathrm{K})$, magnesium $(\mathrm{Mg})$, calcium $(\mathrm{Ca})$, sodium $(\mathrm{Na})$, iron $(\mathrm{Fe})$ and manganese $(\mathrm{Mn})$; the extraradical hyphae of AM fungi, which can extend up to $4 \mathrm{~cm}$ from the root surface, absorb minerals beyond the nutrient depletion zones surrounding the roots and translocate them to the roots (Smith \& Read 2008). 
Arbuscular mycorrhizal fungi also improve rooting and plant establishment, enhance plant tolerance to biotic and abiotic stresses, improve nutrient cycling and enhance plant community diversity (Lee et al. 2013). AM fungi can affect the water balance of both amply watered and drought-stressed host plants (Chitarra et al. 2016). Studies of the distribution and activity of AM fungi can help elucidate the ecological significance of AM associations (Gianinazzi et al. 2010). Experimental studies have shown that AM fungal associations can enhance plant growth, nutrient uptake (Diop et al. 2003; Manimegalai et al. 2011; Vosatka \& Gryndler 2000; Davies et al. 2005; Yao et al. 2002; Dennett et al. 2011) and tolerance of salinity, heavy metals and pathogens in solanaceous crop species (Cuperman et al. 1996; Mohammad \& Mittra 2011; Yao et al. 2002). Nevertheless, information on the occurrence of AM fungal associations in members of the Solanaceae is very limited. Only 25 solanaceous plant species have been assessed for their mycorrhizal status (see Wang \& Qiu 2006; Sekhara Reddy et al. 2007; Muthukumar \& Tamilselvi 2010).

After entering plant roots, AM fungi spread inter- or intracellularly within the roots. The mode of spread can vary greatly within a single plant species. Based on the distribution of fungal structures within roots, AM fungal colonization has been categorized as Arum, Paris and intermediate types. In the Arum type, which is frequent in field crops, linear fungal hyphae spread intracellularly, forming arbuscules on short lateral branches (Smith $\&$ Read 2008). In the Paris type, which is more common in plants growing naturally, the fungal hyphae spread among cells intracellularly, forming hyphal or arbusculate coils (Smith \& Smith 1997; Dickson et al. 2007). The Arum and Paris types are generally termed 'linear' and 'coiling' in relation to the appearance of the longitudinal hyphae within the roots (Brundrett 2004). The intermediate type exhibits characteristics of both the Arum and Paris types, such as the presence of linear hyphae which may be inter- and/or intracellular hyphal and arbusculate coils. Previous studies have examined the diversity and abundance of AM fungal species (e.g., Songachan \& Kayang 2012; Senés-Guerrero et al. 2014) but the colonization patterns of nightshades remain largely unknown. Up to 2007, AM morphology was known only for Datura alba Nees, D. metel L., Lycopersicon esculentum Mill., Nicotiana velutina Wheeler, Solanum ellipticum Vel., S. melongena L., S. surattense Burm. f. and S. verbascifolium L. (Dickson et al. 2007).

Dark septate endophyte (DSE) fungi are darkly pigmented, sterile, regularly septate root-associated fungi which colonize living plant organs, especially roots, without causing any apparent negative effects (Mandyam \& Jumpponen 2005). In DSE fungi-colonized roots, the fungi form a cluster of inflated, rounded, thick-walled cells within the cortical wall, called microsclerotia (Jumpponen \& Trappe 1998). DSE fungi are distributed in different habitats and host plants, suggesting the absence of host specificity (Mandyam \& Jumpponen 2005). The melanin present in the fungal hyphae protects DSE fungi from unfavorable or stressful conditions such as drought and extreme temperature (Mandyam \& Jumpponen 2005). As with AM fungi, information on the occurrence of DSE fungal associations in Solanaceae taxa is also limited. Up to 1998 the presence of DSE associations was reported in only six tropical solanaceous plant species (Jumpponen \& Trappe 1998). Later, DSE fungal associations were reported in three solanaceous plants of southern India (Muthukumar \& Tamilselvi, 2010). More recently, Songachan and Kayang (2012) reported fractional colonization $(<1 \%)$ of DSE fungi in roots of Solanum khasianum C. B. Clarke, S. sisymbrifolium Lam. and S. torvum Sw. growing naturally in Meghalaya, India.

The objective of the present study was to assess the incidence and extent of AM and DSE fungal associations in Solanaceae taxa from the Western Ghats region of southern India. We also determined AM fungal morphology and examined the influence of site and soil characteristics on AM fungal and DSE fungal associations.

\section{Materials AND METHODS}

\section{STUDY SITES AND SAMPLING}

Root samples of 20 solanaceous plant species belonging to seven genera were collected during January 2012 from four different areas in Tamilnadu, India: Erode (site I), 
Coimbatore (site II), Pollachi (site III) and Ooty (site IV) (Tables 1 \& 2). Three plants of each species growing at a site were sampled. Capsicum annuum L., Lycopersicon esculentum Mill., Solanum torvum Sw. and S. trilobatum L. were collected from sites I and II. Capsicum frutescens L. was collected from sites II, III and IV. Solanum melongena L. was collected from sites I, II and IV. Datura metel L. and Solanum nigrum L. were collected from sites I, II, III and IV. Each root was excavated carefully without damaging it, and the fine roots were traced back to the stem to confirm that the collected roots belonged to the intended plant. Collected roots were washed free of soil and fixed in FAA (formalin: glacial acetic acid: 70\% ethyl alcohol; 5:5:90; v:v:v) for processing. Five randomly picked $0-15 \mathrm{~cm}$ soil samples collected from each site were bulked, shade-dried at room temperature and used for soil chemistry analyses.

\section{DETERMINATION OF SOIL CHEMICAL PROPERTIES}

Soil $\mathrm{pH}$ and electrical conductivity (EC) were measured in 1:1 soil: water (v:v) suspensions using digital meters (ELICO, India) soon after the soil samples were brought to the laboratory. Total nitrogen $(\mathrm{N})$ and total phosphorous $(\mathrm{P})$ were determined according to Jackson (1971), and exchangeable potassium (K) was extracted with ammonium acetate and measured using flame photometry (Jackson 1971).

\section{PREPARATION OF ROOTS FOR EXAMINATION}

OF AM AND DSE FUNGI

The fixed roots were washed free of FAA, cleared in $2.5 \% \mathrm{KOH}$ at $90^{\circ} \mathrm{C}$ (Koske \& Gemma 1989) for
45-80 min, acidified with $5 \mathrm{~N} \mathrm{HCl}$ and placed in trypan blue $(0.05 \%$ in lactoglycerol) overnight for staining. Stained fine roots mounted on microscope slides were examined with an Olympus BX 51 compound microscope $(\times 400)$ for the presence AM and DSE fungal structures. The percentage of root length colonized by AM or DSE fungi was estimated according to the magnified intersection method described by McGonigle et al. (1990). Only roots containing arbuscules or arbusculate coils were considered to be AM. The classification of AM morphology was based on whether the fungal hyphae were present mainly as hyphae running through intercellular spaces or within cells as coils, following the descriptions of Dickson (2004). Regularly septate and melanized hyphae were deemed to indicate fungal colonization. DSE fungal colonization and structures were determined as described for AM fungi.

\section{PLANT NOMENCLATURE AND ECONOMIC IMPORTANCE}

Nomenclature and authorities for plants follow The Plant List (Anonymous 2013). Economic importance is given following Henry et al. (1987).

\section{STATISTICAL ANALYSIS}

One-way analysis of variance (ANOVA) was used to test the significance of variation of fungal variables. The paired-sample $t$ test was performed to assess the significance of differences between means for solanaceous plant species occurring at two sites (SPSS, Windows ver. 9). Pearson's correlation coefficient was used to assess the relationship between AM and DSE fungal

Table 1. Site and soil characteristics of the study sites.

\begin{tabular}{lcccc}
\hline \multirow{2}{*}{ Particulars } & \multicolumn{3}{c}{ Sites } \\
\cline { 2 - 5 } & Erode (site I) & Coimbatore (site II) & Pollachi (site III) & Ooty (site IV) \\
\hline Location & $11^{\circ} 30^{\prime} \mathrm{N}$ and $77^{\circ} 14^{\prime} \mathrm{E}$ & $1^{\circ} 04^{\prime} \mathrm{N}$ and $76^{\circ} 93^{\prime} \mathrm{E}$ & $10^{\circ} 40^{\prime} \mathrm{N}$ and $77^{\circ} 1^{\prime} \mathrm{E}$ & $11^{\circ} 24^{\prime} \mathrm{N}$ and \\
& 800 & 1800 & 2286 & 2240 \\
Altitude (m.a.s.l) & 800 & 700 & 823 & 991 \\
Annual rainfall $(\mathrm{mm})$ & 10 & 10 & 6 & 8 \\
Number of plant species collected & sandy clay loam & sandy loam & sandy loam & sandy clay loam \\
\hline Soil type & $8.16 \pm 0.01 \mathrm{c}$ & $8.12 \pm 0.03 \mathrm{c}$ & $7.92 \pm 0.04 \mathrm{~b}$ & $5.70 \pm 0.11 \mathrm{a}$ \\
pH & $0.16 \pm 0.01 \mathrm{a}$ & $0.21 \pm 0.01 \mathrm{~b}$ & $0.16 \pm 0.01 \mathrm{a}$ & $0.25 \pm 0.01 \mathrm{c}$ \\
Electrical conductivity $\left.(\mathrm{dSm})^{-1}\right)^{*}$ & $9.13 \pm 0.07 \mathrm{a}$ & $9.47 \pm 0.04 \mathrm{~b}$ & $9.14 \pm 0.04 \mathrm{a}$ & $90.03 \pm 0.04 \mathrm{a}$ \\
Total nitrogen $(\mathrm{mg} / \mathrm{kg})^{*}$ & $0.93 \pm 0.04 \mathrm{~d}$ & $0.82 \pm 0.03 \mathrm{c}$ & $0.36 \pm 0.02 \mathrm{a}$ & $0.61 \pm 0.03 \mathrm{~b}$ \\
Available phosphorus $(\mathrm{mg} / \mathrm{kg})^{*}$ & $20.03 \pm 0.82 \mathrm{bc}$ & $18.24 \pm 0.52 \mathrm{~b}$ & $16.21 \pm 0.47 \mathrm{a}$ & $20.83 \pm 0.52 \mathrm{c}$ \\
Exchangeable potassium $(\mathrm{mg} / \mathrm{kg})^{*}$ & & & &
\end{tabular}

${ }^{*}$ Means \pm standard error in a row followed by the same letter do not differ significantly $(\mathrm{P}>0.05)$ according to Duncan's Multiple Range Test. 
Table 2. Present and previous reports of the occurrence of arbuscular mycorrhizal (AM) and dark septate endophyte (DSE) fungal associations and AM morphological types in Solanaceae taxa.

\begin{tabular}{|c|c|c|c|c|c|c|c|c|}
\hline \multirow[b]{2}{*}{ Plant species } & \multirow[b]{2}{*}{ Site $^{\mathrm{a}}$} & \multirow[b]{2}{*}{$\mathrm{EI}^{\mathrm{b}}$} & \multirow[b]{2}{*}{$\mathrm{AM}^{\mathrm{c}}$} & \multirow{2}{*}{$\begin{array}{l}\text { AM- } \\
\text { type }^{\text {d }}\end{array}$} & \multirow[b]{2}{*}{$\mathrm{DSE}^{\mathrm{c}}$} & \multicolumn{3}{|c|}{ Previous report ${ }^{\#}$} \\
\hline & & & & & & AM status ${ }^{\mathrm{e}}$ & $\begin{array}{l}\mathrm{AM}- \\
\text { type }^{\mathrm{d}}\end{array}$ & DSE $^{f}$ \\
\hline $\begin{array}{l}\text { Brugmansia sanguinea } \\
\text { (Ruiz \& Pav.) D. Don. }\end{array}$ & IV & $\mathrm{O}, \mathrm{M}$ & + & I3 & + & NR & NR & NR \\
\hline Capsicum frutescens $\mathrm{L}$. & II, III, IV & $\mathrm{V}$ & + & $\mathrm{P}$ & $+/-(\mathrm{III})$ & NR & NR & NR \\
\hline C. аппиит $\mathrm{L}$. & I, II & $\mathrm{V}, \mathrm{M}$ & + & $\mathrm{P}$ & + & $\mathrm{AM}^{1,2,3,4,13}$ & $\mathrm{P}^{5}, \mathrm{~A}^{4}$ & $\operatorname{Tr}^{4,11}$ \\
\hline Datura innoxia Mill. & III & $\mathrm{M}, \mathrm{O}$ & + & I3 & + & NR & NR & NR \\
\hline D. metel L. & I, II, III, IV & $\mathrm{M}, \mathrm{O}$ & + & Ilac & $+/-(\mathrm{I})$ & $\mathrm{AM}^{1,6}$ & $\mathrm{~A}^{6,9}$ & NR \\
\hline D. stramonium $\mathrm{L}$. & I & M & + & $\mathrm{I} 4$ & + & $\mathrm{AM}^{1}$ & NR & $\operatorname{Tr}^{11}$ \\
\hline Lycopersicon esculentum Mill. & I, II & $\mathrm{V}$ & + & $\mathrm{I} 3$ & + & $\mathrm{AM}^{1,6}$ & $\mathrm{I}^{5}$ & $\operatorname{Tr}^{8}$ \\
\hline Nicotiana tabacum $\mathrm{L}$. & I & M & + & Ilac & + & $\mathrm{AM}^{4}$ & $\mathrm{I}^{4}$ & $\operatorname{Tr}^{4}$ \\
\hline Physalis angulata $\mathrm{L}$. & III & M & + & I4 & + & NR & NR & NR \\
\hline S. elaeagnifolium Cau. & II & $\mathrm{M}$ & + & I3 & + & NR & NR & NR \\
\hline Solanum melongena $\mathrm{L}$. & I, II, III & $\mathrm{V}$ & + & I3/P (II) & $+/-(\mathrm{I})$ & $\mathrm{AM}^{4,7}$ & $\mathrm{~A} \& \mathrm{P}^{5}$ & $\operatorname{Tr}^{4}$ \\
\hline S. nigrum $\mathrm{L}$. & I, II, III, IV & $\mathrm{V}, \mathrm{M}$ & + & I3/ P (IV) & + & $\mathrm{AM}+\mathrm{NM}^{1}, \mathrm{AM}^{4}$ & $\mathrm{I}^{4}, \mathrm{P}^{9}$ & $\mathrm{Te}^{8}, \mathrm{NA}^{4}$ \\
\hline S. pseudocapsicum L. & IV & $\mathrm{O}$ & + & $\mathrm{P}$ & + & $\mathrm{NR}$ & NR & NR \\
\hline S. pubescens Willd. & II & $\mathrm{M}$ & + & I3 & - & NR & NR & NR \\
\hline S. sisymbrifolium Lam. & IV & $\mathrm{O}$ & + & $\mathrm{I} 4$ & - & $\mathrm{AM}^{10,12}$ & $\mathrm{P}^{10}$ & $\mathrm{~S} \operatorname{Tr}^{10}, \operatorname{Tr}^{12}$ \\
\hline S. torvum SW. & I, II & $\mathrm{V}, \mathrm{M}$ & + & $\mathrm{P}$ & + & $\mathrm{NM}^{1}, \mathrm{AM}^{4,9,12}$ & $\mathrm{I}^{4}, \mathrm{~A}^{9}$ & $\mathrm{NA}^{4}, \operatorname{Tr}^{12}$ \\
\hline S. trilobatum L. & I, II & M & + & $\mathrm{P}$ & + & NR & NR & NR \\
\hline S. tuberosum $\mathrm{L}$. & IV & $\mathrm{V}$ & + & $\mathrm{P}$ & - & $\mathrm{AM}^{1}$ & NR & $\mathrm{Te}^{8}$ \\
\hline S. viarum Dunal & IV & M & + & $\mathrm{I} 3$ & - & NR & NR & NR \\
\hline S. virginianum $\mathrm{L}$. & I & $\mathrm{M}$ & + & I 4 & + & NR & NR & NR \\
\hline
\end{tabular}

${ }^{a}$ I, II, III and IV indicates Erode, Coimbatore, Pollachi and Ooty; ${ }^{\text {b }}$ EI - economic importance, V - vegetable; O - ornamental; $\mathrm{M}$ - medicinal; ${ }^{\mathrm{c}} \mathrm{AM}$ - arbuscular mycorrhizal; DSE - dark septate endophyte; + - presence; - - absence; ${ }^{\mathrm{d}} \mathrm{A}-$ Arum-type; I - intermediate-type; P - Paris-type; ${ }^{\mathrm{e}} \mathrm{AM}$ - arbuscular mycorrhizal; NM - non-mycorrhizal; NR - no report; ${ }^{\mathrm{f}} \mathrm{Tr}-\mathrm{tropical}$; Te - temperate; STr - subtropical; NR - no report; NA - no association.

${ }^{*} 1$ Wang \& Qiu (2006), ${ }^{2}$ Li et al. (2007), ${ }^{3}$ Castillo et al. (2009), ${ }^{4}$ Muthukumar \& Tamilselvi (2010), ${ }^{5}$ Dickson et al. (2007), ${ }^{6}$ Muthukumar et al. (2006), ${ }^{7}$ Akond et al. (2008), ${ }^{8}$ Jumpponen \& Trappe (1998), ${ }^{9}$ Muthukumar \& Prakash (2009), ${ }^{10}$ Fracchia et al. (2009), ${ }^{11}$ Zhang et al. (2011), ${ }^{12}$ Songachan \& Kyang (2012), ${ }^{13}$ Gashua et al. (2015).

variables. Percentage data on root colonization were arcsine-transformed prior to analysis.

\section{RESULTS}

\section{SOIL CHARACTERISTICS}

The soil was sandy loam at sites II and III, and sandy clay loam at sites I and IV (Table 2). The soil was acidic at site IV (5.70) and basic at the other sites. Electrical conductivity ranged between $0.16 \mathrm{dSm}^{-1}$ (sites I and III) and $0.24 \mathrm{dSm}^{-1}$ (sites II and IV). The soil was low in nutrients, especially phosphorus, which ranged from $3.6 \mathrm{~kg} \mathrm{ha}^{-1}$ (site III) to $9 \mathrm{~kg} \mathrm{ha}^{-1}$ (site I). Total nitrogen in soils was similar $\left(90 \mathrm{~kg} \mathrm{ha}^{-1}\right)$ at all sites. Exchangeable potassium in soil was moderately high at all the sites except at site III (162 kg ha-1) (Table 2).

\section{DISTRIBUTION OF FUNGAL ASSOCIATION}

All 20 solanaceous plants examined were mycorrhizal (Table 2). The mycorrhiza in Solanaceae was of AM type (Fig. 1). Entry of fungal hyphae into roots was preceded by the formation of an appressorium on the root surface, and an infection peg penetrating the rhizodermal cells (Fig. 1a-c). The hyphae from the infection peg coiled or were linear in the epidermal cells (Fig. 1c, d). Colonization in the cortical region was by means of linear hyphae 
which were inter- or intracellular, and hyphal or arbusculate coils and vesicles (Fig. 1e-p). The linear hyphae sometimes bore distinct oil globules; they were smooth or contained peg-like projections (Fig. 1f, n). The vesicles were mostly intracellular and ranged in number from one to three per cell (Fig. 1q, r). Occasionally, AM fungal sporulating structures such as soporiferous saccules were seen in the cortex of S. nigrum and L. esculentum from site I (Fig. 1s).

DSE fungal colonization was found in only 16 (80\%) of the 20 plant species examined (Table 2). There were no DSE fungal associations in Solanum tuberosum, $S$. viarum, $S$. sisymbrifolium and $S$. pubescens. Capsicum frutescens, Datura metal and Solanum melangena from certain sites showed no DSE fungal colonization, though root samples of these species from other sites did contain DSE fungal structures.

\section{EXTENT OF AM COLONIZATION}

The extent of AM fungal colonization and the percentage of root length with different AM fungal structures varied significantly between species (Table 3). Total colonization percentage (\%RLTC) generally was high, ranging between $34.00 \%$ in $\mathrm{So}$ lanum trilobatum (site I) and $81.15 \%$ in $S$. viarum (site IV). The percentage of root length with hyphae (\%RLH) ranged between $11.18 \%$ in $S$. nigrum (site I) and $26.69 \%$ in $S$. viarum. The percentage of root length with arbusculate coils (\%RLAC) varied between $19.55 \%$ in Datura metel (site IV) and $49.53 \%$ in $S$. nigrum (site IV). The percentage of root length with hyphal coils (\%RLHC) ranged from $4.43 \%$ in $S$. melangena (site I) to $34.56 \%$ in Capsicum frutescens (site II). The percentage of root length with vesicles $(\% \mathrm{RLV})$ ranged between $0.76 \%$ in S. nigrum (site I) and $34 \%$ in S. trilobatum (site I). Vesicles were absent in 13 root samples.

Capsicum annuum, Lycopersicon esculentum, Solanum trilobatum and S. torvum from two different sites were examined (Table 2). There was no significant variation in the \%RLTC or AM fungal structures in L. esculentum, except for \%RLHC (Table 4). For $C$. annuum, \%RLAC was the only
AM fungal variable that exhibited significant variation between sites. \%RLH was the only AM fungal variable that exhibited significant variation in S. trilobatum and S. torvum.

Capsicum frutescens showed no variation of AM fungal variables between sites. In Solanum melongena, the only AM fungal variables that showed significant variation between sites were $\%$ RLH and \%RLHC. In Datura metel, only $\%$ RLAC and \%RLHC exhibited significant between-site variation. In Solanum nigrum, \%RLH, $\%$ RLAC and \%RLV exhibited significant variation between sites.

Soil $\mathrm{pH}$ was significantly and negatively correlated with \%RLH $(\mathrm{r}=-0.361 ; \mathrm{p}<0.04 ; \mathrm{n}=33)$ and $\%$ RLTC $(\mathrm{r}=-0.464 ; \mathrm{p}<0.01 ; \mathrm{n}=33)$. As \%RLTC was significantly and positively correlated with soil EC $(r=-0.365 ; p<0.04 ; n=33)$, it was significantly and negatively correlated with $\mathrm{P}(\mathrm{r}=-0.400$; $\mathrm{p}<0.02 ; \mathrm{n}=33$ ).

\section{AM MORPHOLOGICAL TYPES}

Six solanaceous species had typical Paris-type AM morphology, characterized by the presence of hyphal coils, with the rare occurrence of arbusculate coils and intracellular vesicles (Table 2, Fig. 1). The majority of investigated species (12) had intracellular hyphal coils or arbusculate coils with inter- or intracellular linear hyphae, characteristic of intermediate-type AM morphology. Two of these species had intermediate-type 1 (I1); intermediate-type 3 (I3) and intermediate-type 4 (I4) morphology were seen in five species each. Species with I3 morphology had intracellular linear hyphae with intracellular hyphal or arbusculate coils; in those with I4 morphology the linear hyphae were intercellular, with intracellular hyphal or arbusculate coils. In Nicotiana tabacum and Datura metel, I1 morphology was characterized by the presence of intercellular linear hyphae with intracellular arbusculate coils developing on their lateral branches (Fig. 1I, p). Solanum melongena had intermediate I3 type in samples from sites I and III, and Paris-type in samples from site II. Solanum nigrum had Paris-type morphology in material from site IV, and intermediate I3 in that 
from sites I, II and III. Typical Arum-type AM morphology was not observed in any of the root samples examined (Table 2). Solanum trilobatum had Paris-type morphology in samples from site II, and lacked AM fungal structures except for hyphae and vesicles in samples from site I.

\section{EXTENT OF DSE COLONIZATION}

The percentage of total root length with DSE fungal hyphae (\%RLDSTC) ranged between $<1 \%$ in Solanum nigrum (site IV) and $36.42 \%$ in S. trilobatum (site I) (Table 4). Microsclerotia or moniliform hyphae were not observed in any of the root samples examined. \%RLDST exhibited significant differences between sites in Capsicum annuum, C. frutescens, Datura metel, Solanum nigrum, S. melongena and S. trilobatum. \%RLDTC was significantly and positively correlated with $\% \operatorname{RLV}(\mathrm{r}=0.516 ; \mathrm{p}<0.002 ; \mathrm{n}=33)$ and negatively with \%RLAC $(\mathrm{r}=-0.510 ; \mathrm{p}<0.002 ; \mathrm{n}=33)$. We noted a significant negative correlation between $\%$ RLDSTC and \%RLTC $(\mathrm{r}=0.64 ; \mathrm{P}<0.001$; $\mathrm{n}=34)$.

\section{DisCUSSION}

Arbuscular mycorrhizas are multifunctional in both natural systems and agroecosystems, and enhance the physical, chemical and biological quality of soils (Cardoso \& Kuyper 2006). For nine of the solanaceous species we examined this is the first assessment of their mycorrhizal status. The occurrence of AM fungal associations in all the examined plant species from different sites confirms the widespread occurrence of AM fungal associations in this family. Some of the solanaceous plants we examined, such as Capsicum annuum, Nicotiana tabacum, Solanum melongena, S. nigrum, S. torvum, S. trilobatum, S. tuberosum, Datura metel, D. stromanium and Lycopersicon esculentum, were reported to be mycorrhizal in earlier work (Ragupathy \& Mahadevan, 1993; Muthukumar \& Udaiyan 2000; Wang \& Qiu 2006; Muthukumar et al. 2006; Li et al. 2007; Akond et al. 2008; Wang \& Shi 2008; Muthukumar \& Prakash 2009; Muthukumar \& Tamilselvi 2010). Our finding of the presence of AM colonization in roots of Datura innoxia stands in contrast to observations by Raghupathy and Mahadevan (1993); they found it to be nonmycorrhizal in material from the tropical plains of Tamilnadu, India. Though there is no detailed information on the extent of variation of intraradical structures of different AM fungi, the available evidence suggests that in certain instances the intraradical structures produced may indicate the AM fungal taxa involved. For example, members of Gigasporaceae are known to possess intraradical hyphae with knob-like projections and inflated areas (Bentivenga \& Morton 1995). The peg-like projections we observed on the intraradical hyphal surface suggests possible colonization by members of the Gigasporaceae. Similar intraradical hyphal morphology has also been reported in pteridophytes and cycads (Muthukumar \& Udaiyan 2002; Muthuraja et al. 2014). Structures resembling the soporiferous saccules of Acaulosporaceae were also observed in roots of certain solanaceous taxa. Sporulation of Acaulosporaceae taxa within plant roots has been reported previously (e.g., Schultz et al. 1999).

The extent of AM colonization observed in the present study $(34-81 \%)$ is within the range

Fig. 1. Arbuscular mycorrhizal (AM) and dark septate endophyte (DSE) fungal colonization in Solanaceae roots. a - appressorium (ap) on root surface and infection peg (arrow head) in Solanum nigrum; b \& c - extraradical mycelium (em), appressorium (ap) and fungal hyphae (f) in rhizodermal cells (rc) of S. pubescens and Lycopersicon esculentum; d - intracellular linear hyphae (lh) in Brumansia sanguine; e - hyphal coils (hc) in cortical cells of Capcicum frutescens; $\mathrm{f}$ - intracellular hyphae with oil droplets (arrowheads) in Datura innoxia; $\mathrm{g}$ - arbuscules (a) in Solanum nigrum; $\mathrm{h}$ - arbusculate coils (ac) in Lycopersicon esculentum; i - arbusculate coil (ac) and intercellular hyphae (arrow heads) in Nicotiana tabacum; $\mathrm{j}$ - hyphal coil in Solanum pseudocapsicum; $\mathrm{k}$ - arbuscules in S. pubescens; 1 - intracellular hyphae (ih) bearing arbuscules in $S$. viarum; $\mathrm{m}$ - arbusculate coils (ac) in Datura stramonium; $\mathrm{n}$ - intracellular hyphae with peg-like projections in Nicotiana tabacum; o - hyphal coil (hc) in Solanum trilobatum; $\mathrm{p}$ - intercellular hyphae (arrow head) and arbusculate coil in Datura metel; $\mathrm{q}$ - intracellular vesicle (v) in D. innoxia; $\mathrm{r}$ - intracellular vesicles (v) in Lycopersicon esculentum; $\mathrm{s}$ - sporiferous saccule (ss) in cortex of Solanum nigrum; $\mathrm{t} \& \mathrm{u}-$ melanized hyphae of DSE fungi in $S$. trilobatum $(\mathrm{t})$ and $S$. melongena $(\mathrm{u})$. Scale bars $=25 \mu \mathrm{m}$. 





Table 3. Extent of arbuscular mycorrhizal (AM) and dark septate endophyte (DSE) fungal associations in members of the nightshade family.

\begin{tabular}{|c|c|c|c|c|c|c|c|}
\hline \multirow[t]{2}{*}{ Plant species } & \multirow{2}{*}{ Site $^{\mathrm{a}}$} & \multicolumn{5}{|c|}{$\%$ AM colonization ${ }^{\mathrm{b}}$} & \multirow{2}{*}{$\begin{array}{c}\text { \%DSE } \\
\text { colonization }^{\mathrm{c}} \\
\% \text { RLDSTC }\end{array}$} \\
\hline & & $\%$ RLH & $\%$ RLAC & $\%$ RLHC & $\%$ RLV & $\%$ RLTC & \\
\hline Brugmansia sanguinea & IV & $19.37 \pm 1.41^{\mathrm{d}}$ & $28.12 \pm 2.16$ & $22.49 \pm 0.70$ & - & $69.98 \pm 0.74$ & $10.30 \pm 1.89$ \\
\hline \multirow[t]{2}{*}{ Capsicum аппиит } & I & - & $35.89 \pm 1.29$ & $21.04 \pm 3.86$ & $5.76 \pm 2.91$ & $62.68 \pm 1.53$ & $5.26 \pm 1.40$ \\
\hline & II & - & $37.87 \pm 1.14$ & $26.30 \pm 2.05$ & - & $64.17 \pm 3.04$ & $11.65 \pm 1.59$ \\
\hline \multirow[t]{3}{*}{ C. frutescens } & II & - & $30.83 \pm 0.32$ & $34.56 \pm 1.58$ & $6.37 \pm 3.36$ & $71.76 \pm 2.55$ & $11.42 \pm 2.15$ \\
\hline & III & - & $37.93 \pm 4.55$ & $28.87 \pm 5.65$ & $4.44 \pm 3.39$ & $71.25 \pm 3.73$ & - \\
\hline & IV & - & $39.35 \pm 3.18$ & $26.28 \pm 2.06$ & - & $65.63 \pm 1.16$ & $18.07 \pm 3.18$ \\
\hline \multirow[t]{4}{*}{ Datura metel } & I & $22.08 \pm 1.95$ & $38.55 \pm 4.05$ & $5.46 \pm 0.47$ & $5.65 \pm 1.83$ & $71.74 \pm 2.77$ & - \\
\hline & II & $18.73 \pm 1.23$ & $21.08 \pm 1.22$ & $23.46 \pm 2.43$ & $8.60 \pm 0.81$ & $71.87 \pm 1.36$ & $7.03 \pm 0.05$ \\
\hline & III & $16.02 \pm 1.09$ & $28.52 \pm 3.29$ & $17.78 \pm 1.11$ & $7.22 \pm 1.11$ & $69.54 \pm 2.82$ & $8.98 \pm 2.52$ \\
\hline & IV & $22.85 \pm 3.51$ & $19.55 \pm 1.86$ & $26.04 \pm 3.75$ & $3.51 \pm 1.90$ & $71.95 \pm 0.11$ & $7.90 \pm 2.60$ \\
\hline D. stramonium & I & $14.19 \pm 2.00$ & $30.47 \pm 3.57$ & $5.45 \pm 1.93$ & - & $50.11 \pm 1.59$ & $10.56 \pm 2.16$ \\
\hline D. innoxia & III & $14.64 \pm 1.37$ & $26.41 \pm 1.44$ & $22.43 \pm 2.28$ & $12.44 \pm 1.87$ & $75.91 \pm 2.11$ & $9.10 \pm 0.96$ \\
\hline \multirow[t]{2}{*}{ Lycopersicon esculentum } & I & $13.54 \pm 2.63$ & $25.12 \pm 3.12$ & $10.65 \pm 3.78$ & $14.79 \pm 3.88$ & $64.11 \pm 1.31$ & $7.14 \pm 4.32$ \\
\hline & II & $16.17 \pm 1.20$ & $28.70 \pm 3.34$ & $17.16 \pm 2.56$ & $3.70 \pm 2.45$ & $65.74 \pm 0.92$ & $6.27 \pm 0.71$ \\
\hline Nicotiana tabacum & I & $14.76 \pm 2.12$ & $23.86 \pm 2.37$ & $20.62 \pm 1.89$ & $1.67 \pm 0.84$ & $60.90 \pm 4.24$ & $15.85 \pm 2.67$ \\
\hline Physalis angulata & III & $22.27 \pm 2.78$ & $33.03 \pm 4.06$ & $21.22 \pm 3.13$ & - & $76.52 \pm 3.78$ & $4.12 \pm 0.57$ \\
\hline \multirow[t]{3}{*}{ Solanum melongena } & I & $17.08 \pm 3.17$ & $46.94 \pm 4.27$ & $4.43 \pm 1.27$ & $2.13 \pm 2.13$ & $70.58 \pm 3.99$ & - \\
\hline & II & - & $38.65 \pm 2.17$ & $29.44 \pm 3.48$ & - & $68.10 \pm 1.98$ & $13.44 \pm 2.19$ \\
\hline & III & $18.95 \pm 4.22$ & $45.08 \pm 4.80$ & $5.07 \pm 1.14$ & $4.26 \pm 0.36$ & $73.36 \pm 0.64$ & $8.41 \pm 1.12$ \\
\hline \multirow[t]{4}{*}{ S. nigrum } & I & $11.18 \pm 0.40$ & $47.44 \pm 2.58$ & $11.81 \pm 1.59$ & $0.76 \pm 0.76$ & $71.19 \pm 3.24$ & $2.03 \pm 0.15$ \\
\hline & II & $19.05 \pm 4.13$ & $30.30 \pm 2.08$ & $19.52 \pm 3.69$ & - & $68.87 \pm 0.30$ & $7.49 \pm 0.63$ \\
\hline & III & $18.07 \pm 1.86$ & $24.43 \pm 2.07$ & $23.53 \pm 1.60$ & $7.19 \pm 1.61$ & $73.22 \pm 2.68$ & $9.47 \pm 0.32$ \\
\hline & IV & - & $49.53 \pm 4.35$ & $18.02 \pm 4.50$ & - & $67.55 \pm 1.95$ & $0.79 \pm 0.19$ \\
\hline S. virginianum & I & $22.72 \pm 3.07$ & $44.03 \pm 2.63$ & $13.51 \pm 3.24$ & - & $80.26 \pm 4.74$ & $6.08 \pm 4.07$ \\
\hline \multirow[t]{2}{*}{ S. trilobatum } & I & - & - & - & $34.00 \pm 6.33$ & $34.00 \pm 6.33$ & $36.42 \pm 2.89$ \\
\hline & II & - & $33.97 \pm 3.31$ & $24.93 \pm 4.68$ & $11.01 \pm 1.67$ & $69.91 \pm 3.01$ & $1.90 \pm 1.90$ \\
\hline \multirow[t]{2}{*}{ S. torvum } & I & - & $38.55 \pm 0.90$ & $18.42 \pm 1.32$ & $3.56 \pm 0.99$ & $60.54 \pm 1.37$ & $7.61 \pm 3.12$ \\
\hline & II & - & $29.49 \pm 2.60$ & $31.41 \pm 0.64$ & $9.33 \pm 0.84$ & $70.23 \pm 1.37$ & $6.91 \pm 1.96$ \\
\hline S. tuberosum & IV & - & $31.02 \pm 8.07$ & $17.71 \pm 4.65$ & - & $48.73 \pm 4.74$ & - \\
\hline S. viarum & IV & $26.69 \pm 2.53$ & $33.69 \pm 3.18$ & $20.77 \pm 1.09$ & - & $81.15 \pm 2.26$ & - \\
\hline S. sisymbrifolium & IV & $23.26 \pm 5.62$ & $23.33 \pm 1.50$ & $24.12 \pm 6.03$ & $9.96 \pm 0.82$ & $80.66 \pm 2.85$ & - \\
\hline S. pseudocapsicum & IV & - & $39.45 \pm 2.15$ & $32.78 \pm 5.13$ & - & $72.23 \pm 4.17$ & $7.63 \pm 1.95$ \\
\hline S. pubescens & II & $22.35 \pm 0.97$ & $21.29 \pm 2.69$ & $24.84 \pm 2.91$ & $9.46 \pm 2.17$ & $77.94 \pm 2.08$ & - \\
\hline S. elaeagnifolium & II & $15.34 \pm 1.10$ & $25.35 \pm 1.60$ & $19.72 \pm 2.36$ & - & $60.41 \pm 1.34$ & $9.36 \pm 0.52$ \\
\hline
\end{tabular}

a I, II, III and IV indicates Erode, Coimbatore, Pollachi and Ooty; ${ }^{\mathrm{b}} \%$ RLH, \%RLA, \%RLV, \%RLHC and \%RLTC indicate percentage of root length with hyphae, arbuscules/arbusculate coils, vesicles, hyphal coils and total colonization; ${ }^{\mathrm{c}} \% \mathrm{RLDSTC}$ indicates percentage of root length with DSE total colonization; ${ }^{\mathrm{d}}$ Mean $\pm \mathrm{SE}$.

(59-97\%) reported earlier for solanaceous crop species by Muthukumar and Tamilselvi (2010). The AM colonization levels we found are higher than those reported for three solanaceous plants (35-38\%) from Meghalaya, India (Songachan \& Kayang 2012). Akond et al. (2008) also reported low incidence of mycorrhizal associations (36\%) in Solanaceae vegetable crop plants from Bangladesh. The moderate mean level of AM fungal colonization (69\%) observed in the present study is consistent with findings from Muthukumar and Udaiyan (2000), Muthukumar et al. (2006) and 
Table 4. Summary of F and t statistics for arbuscular mycorrhizal (AM) and dark septate endophyte (DSE) fungal variables for Solanaceae root samples from different sites.

\begin{tabular}{|c|c|c|c|c|c|c|c|}
\hline \multirow{2}{*}{ Plant species } & \multirow{2}{*}{ Test df } & \multicolumn{5}{|c|}{$\mathrm{AM}^{\mathrm{a}}$} & \multirow{2}{*}{$\begin{array}{c}\text { DSE }^{\mathrm{b}} \\
\text { \%RLDSTC }\end{array}$} \\
\hline & & $\%$ RLH & $\%$ RLA & $\%$ RLHC & $\%$ RLV & $\%$ RLTC & \\
\hline Capsicum annuит & $\mathrm{t}_{2}$ & - & $-2.9775^{*}$ & $-0.8997 \mathrm{~ns}$ & $1.97803 \mathrm{~ns}$ & $-0.5718 \mathrm{~ns}$ & $-4.6023^{*}$ \\
\hline Lycopersicon esculentum & $\mathrm{t}_{2}$ & $-1.8218 \mathrm{~ns}$ & -0.8218 & $-3.5722^{*}$ & $1.7533 \mathrm{~ns}$ & $-0.8845 \mathrm{~ns}$ & $0.2407 \mathrm{~ns}$ \\
\hline Solanum trilobatum & $\mathrm{t}_{2}$ & - & $-10.2467^{* *}$ & $-5.3299^{*}$ & $2.8766^{*}$ & $-4.4651^{*}$ & $7.5393^{* *}$ \\
\hline Solanum torvum & $\mathrm{t}_{2}$ & - & $3.8876^{*}$ & $-9.6115^{* *}$ & $-30.739^{* * *}$ & $-4.963^{*}$ & $0.5993 \mathrm{~ns}$ \\
\hline Capsicum frutescens & $\mathrm{F}_{2,6}$ & - & $2.0258 \mathrm{~ns}$ & $1.3945 \mathrm{~ns}$ & $1.4028 \mathrm{~ns}$ & $1.5948 \mathrm{~ns}$ & $16.956^{* *}$ \\
\hline Solanum melongena & $\mathrm{F}_{2,6}$ & $11.748^{* *}$ & $1.2325 \mathrm{~ns}$ & $40.6019^{* * *}$ & $2.9265 \mathrm{~ns}$ & $1.0289 \mathrm{~ns}$ & $22.9518^{* *}$ \\
\hline Datura metel & $\mathrm{F}_{3,8}$ & $2.1139 \mathrm{~ns}$ & $9.3752^{* *}$ & $15.6466^{* *}$ & $2.1593 \mathrm{~ns}$ & $0.3072 \mathrm{~ns}$ & $5.0443^{*}$ \\
\hline Solanum nigrum & $\mathrm{F}_{3,8}$ & $14.9015^{* *}$ & $18.1577^{* * *}$ & $2.4293 \mathrm{~ns}$ & $15.4594^{* * *}$ & $1.666 \mathrm{~ns}$ & $60.730^{* * *}$ \\
\hline
\end{tabular}

a $\%$ RLH, \%RLAC, \%RLV, \%RLHC and \%RLTC indicates percentage of root length with hyphae, arbuscules/arbusculate coils, vesicles, hyphal coils and total colonization; ${ }^{\mathrm{b}} \% \mathrm{RLDSTC}$ indicate percentage of root length with DSE total colonization. ns - not significant; ${ }^{*},{ }^{* *},{ }^{* * *}-$ significant at $\mathrm{P}<0.05, \mathrm{P}<0.01$, and $\mathrm{P}<0.001$ respectively.

Fracchia et al. (2009) for mean AM colonization levels in solanaceous plant species: $54 \%$ in material from the Western Ghats, and 70\% in material from the Chacco Serrano Woodland, central Argentina. We found that Solanum melongena had $71 \%$ of its root length colonized by AM fungi, whereas Akond et al. (2008) reported a much lower colonization level (38\%) for the same species. The high colonization levels we observed in solanaceous plant roots may be due in part to sampling time - summer, when plants tend to have high photosynthetic activity, resulting in more allocation of carbon to roots and AM fungi, resulting in higher colonization (Shamim et al. 1994). Also, we sampled the plants in their vegetative stage, and the soil at all the study sites had low P levels, a factor which may have also contributed to the high percentages of root length colonized by AM fungi.

Here we reported AM morphology for the first time in 12 plant species. In this study, $8(40 \%)$ of the 20 plant species had Paris-type AM morphology, higher than the $15 \%$ reported for members of this family by Dickson et al. (2007). Our finding of the absence of typical Arum-type morphology in this family contrasts with findings from Fracchia et al. (2009), who reported Arum-type AM morphology in 2 of the 8 taxa they examined. Intermediatetype morphology was dominant (present in 14 of our 20 species), which is in line with findings by Muthukumar and Tamilselvi (2010): 75\% of the solanaceous crop species they examined had intermediate-type AM morphology. Lycopersicon esculentum (Dickson et al. 2007) and Nicotiana tabacum (Muthukumar \& Tamilselvi 2010) have been shown to possess intermediate-type morphology. In intermediate-type 1 (I1) colonization, the lateral hyphae developing from intercellular linear hyphae and penetrating the cortical cells bear Arum-type arbuscules (Dickson 2004). In N. tabacum and Datura metel, the lateral hyphae originating from intercellular linear hyphae and penetrating the cortical cells produced intracellular arbusculate coils instead of arbuscules. This type appears to be a variant of I1 proposed by Dickson (2004). We designate it as I1 ac.

In $S$. nigrum we found intermediate- and Paristype morphologies in material from different sites, supporting observations by Muthukumar and Prakash (2009) and Muthukumar and Tamilselvi (2010), who noted Paris-type and intermediatetype morphology in material of this species from different tropical agroecosystems. Solanum sisymbrifolium, which Fracchia et al. (2009) found to possess Paris-type AM morphology in samples from the Chacco Serrano Woodland, had intermediate-type AM morphology in material from our site IV. Possibly the difference is due to the same host species being colonized by different fungal species at different sites, as previous work has clearly shown that AM fungal species can modify the colonization patterns of their associated plant 
species to a certain extent (see Dickson et al. 2007 and references therein).

Our finding of a negative correlation between AM fungal colonization and soil $\mathrm{pH}$ is in agreement with other studies in which such a relationship was found in coconut, potato and medicinal plants (Das \& Kayang 2010; Rajeshkumar et al. 2015; Wang \& Jiang 2015). A number of soil and fungal factors are affected by soil $\mathrm{pH}$. For example, germination of AM fungal spores and the development of extraradical hyphae are influenced by changes in soil pH (Hepper 1984; van Aarle et al. 2002). The availability of nutrients in the soil is also influenced by soil $\mathrm{pH}$ (Xu et al. 2016), and that may be part of the effect of soil $\mathrm{pH}$ on $\mathrm{AM}$ fungal colonization. In contrast to findings by Halder et al. (2015) and Wang and Jiang (2015), we obtained a positive correlation between soil EC and AM fungal colonization. Soil electrical conductivity, which is an excellent indicator of nutrient availability, was low in our soil samples. Although soils with EC less than $1 \mathrm{dS} / \mathrm{m}$ are considered to be nonsaline and do not affect microbial processes, soil EC in the range of $0.028-0.270 \mathrm{dS} / \mathrm{m}$ is reported to negatively influence AM fungal colonization (Halder et al. 2015; Wang \& Jiang 2015). However, Rajeshkumar et al. (2015) reported a significant positive correlation between soil EC and root length colonized by AM fungi in coconut growing in soils having an EC range of $0.018-0.122 \mathrm{dS} / \mathrm{m}$. As inherent soil and climatic factors modulate the effect of EC on biological processes, the divergent results on the influence of EC on AM fungal colonization in these studies are tenable. A number of AM fungal processes such as spore germination and mycorrhization are affected by increasing soil $\mathrm{P}$, so a negative correlation between soil $\mathrm{P}$ and AM fungal colonization is not surprising (Liu et al. 2016).

Melanized, darkly pigmented sterile hyphae were observed in the root cortex of $80 \%$ of the examined solanaceous taxa, higher than the $65 \%$ figure reported for members of this family from the Chacco Serrano Woodland, Argentina (Fracchia et al. 2009), but in agreement with previous studies reporting a high frequency of DSE fungal species in herbaceous plant species (Ruotsalainen et al., 2002; Urcelay 2002; Barrow 2003). Solanaceous plants have a high affinity for DSE fungi. The highest number of DSE fungal isolates have frequently been obtained from roots of solanaceous plants (Diene et al. 2014). For example, Narisawa et al. (2007) showed that eggplant was a particularly effective species for baiting the DSE fungus Heteroconium chaetospira from the soil. Here we reported ten plant species as hosts for DSE fungi for the first time. Our finding of DSE fungal associations in Capsicum annuum, Nicotiana tabacum and Solanum melongena extend the presence of this association in tropical agroecosystems $(\mathrm{Mu}-$ thukumar \& Tamilselvi 2010). Colonization of $S$. tuberosum and $S$. nigrum by DSE fungi, which we report here, was previously described in those species from temperate agroecosystems (Jumpponen \& Trappe 1998). The effect of DSE on host plants differs depending on the host and on growth conditions. Their abundance in natural ecosystems is ubiquitous and is thought to be important in any ecosystem. We determined that the DSE-colonized plants also had AM fungal associations, as others have found (Sengupta et al. 1989; Muthukumar et al. 2006; Muthukumar \& Tamilselvi 2010). Chaudhary et al. (2009) contended that the simultaneous occurrence of DSE and AM fungi indicates the dynamic nature of the endophyte community in natural ecosystems. During unfavorable conditions, DSE fungi can function as mutualists by taking up water and nutrients from the soil and translocating them to plant roots (Mandyam \& Jumpponen 2005). The negative correlation between AM and DSE fungal colonization agrees with statements by Muthukumar and Tamilselvi (2010) who reported a similar relationship in crop plants. On the other hand, Songachan and Kayang (2012) reported a positive correlation between these fungal variables in roots of three Solanum species. We found that the share of AM fungal colonization in roots of solanaceous plants was 4-fold to 86-fold higher than the share of DSE fungi. A low share of root length colonization $(<1 \%)$ by DSE fungi was reported by Songachan and Kayang (2012). The negative correlation between the AM and DSE fungal variables and the low percentage of root length colonization by DSE fungi clearly suggest 
an interaction between these fungal types within plant roots. Generally, DSE fungi are known to act as mutualists in improving plant growth and yield only under conditions that are unfavorable for AM fungi, and the direct influence of AM fungi on DSE fungi is yet to be demonstrated as it has for the ectomycorrhizal fungi. For example, the degree of mycorrhization by the ectomycorrhizal fungus Hebeloma crustuliniforme has been shown to significantly reduce the biomass of the DSE fungal Phialocephala fortinii s.l.-Acephala applanata species complex in Norway spruce (Picea abies) roots (Reininger \& Sieber 2013).

This study found AM and DSE fungal associations in solanaceous plants. Although the effects of AM fungi on growth and nutrient uptake have been demonstrated in solanaceous crops, such benefits are yet to be established for DSE fungi. As many solanaceous crops are propagated in nurseries and in vitro, early association of seedlings or plantlets with efficient endorhizal fungal symbionts might enhance their survival and growth in field conditions.

ACKNOWLEDGEMENTS. We are grateful to the reviewers for their constructive inputs.

\section{REFERENCES}

Akond M. A., Mubassara S., Rahman M. M., Alam S. \& KHAN Z. U. M. 2008. Status of vesicular arbuscular (VA) mycorrhizae in vegetable crop plants of Bangladesh. World Journal of Agricultural Sciences 4: 704-708.

AnONYmous 2013. The Plant List. Version 1.1. [10 January 2017]. http://www.theplantlist.org.

Barrow J. R. 2003. A typical morphology of dark septate fungal root endophytes of Bouteloua in arid south western USA range lands. Mycorrhiza 13: 239-247.

Bentivenga S. P. \& Morton J. B. 1995. A monograph of the genus Gigaspora, incorporating developmental patterns of morphological characters. Mycologia 87: 719-731.

BRUNDRETT M. 2004. Diversity and classification of mycorrhizal associations. Biol. Rev. 79: 473-495.

Cardoso I. M. \& Kuyper T. W. 2006. Mycorrhizas and tropical soil fertility. Agric. Eco-Syst. Environm. 116: 72-84.

Castillo C. R., Sotomayor L. S., Ortiz C. O., Leonelli G. C., Borie F. B. \& Rubio R. H. 2009. Effect of arbuscular mycorrhizal fungi on an ecological crop of chilli peppers (Capsicum annum L.). Chilean Journal of Agricultural Research 69: 79-87.
Chaudhary M. S., Rahman S. U., Ismaiel M. S., Sarwar G., Saeed B. \& Nassim F. H. 2009. Coexistence of arbuscular mycorrhizae and dark septate endophytic fungi in an undisturbed and a disturbed site of an arid ecosystem. Symbiosis 49: 19-28.

Chitarra W., Pagliarani C., Maserti B., Lumini E., Siciliano I., Cascone P., Schubert A., Gambino G., BaleSTRINI R., \& GUERRIERI E. 2016. Insights on the impact of arbuscular mycorrhizal symbiosis on tomato tolerance to water stress. Plant Physiol. (Lancaster) 171: 1009-1023.

Chowański S., Adamski Z., Marciniak P., Rosiński G., BüYüKgüZel E., BÜYÜKgüZel K., Falabella P., Scrano L., Ventrella E., Lelario F., \& Bufo S. A. 2016. A review of bioinsecticidal activity of Solanaceae alkaloids. Toxins 8(3): 1-28. doi: 10.3390/toxins 8030060 .

Cuperman R. H., Martin C. A. \& Stutz J. C. 1996. Tomato growth in response to salinity and arbuscular mycorrhizal fungi from saline and non saline soils. HortScience 31: 341-344.

Das P. \& Kayang H. 2010. Association of dark septate endophytes and arbuscular mycorrhizal fungi in potato under field conditions in the northeast region of India. Mycology 1: $171-178$.

Davies JR F. T., Calderón C. \& Huaman Z. 2005. Influence of arbuscular mycorrhiza indigenous to Peru and a flavonoid on growth, yield and leaf elemental concentration of 'Yungay' potatoes (Solanum tubersoum L.). HortScience 40: 381-385.

Dennett A. L., Burgess L. W., McGee P. A. \& Ryder M. H. 2011. Arbuscular mycorrhizal associations in Solanum centrale (bush tomato), a perennial sub-shrub from the arid zone of Australia. J. Arid Environm. 75: 688-694.

Dickson S. 2004. The Arum-Paris continuum of mycorrhizal symbioses. New Phytol. 163: 187-200.

Dickson S., Smith F. A. \& Smith S. E. 2007. Structural differences in arbuscular mycorrhizal symbiosis: more than 100 years after Gallaud, where next? Mycorrhiza 17: 375-393.

Diene O., Sakagami N. \& Narisawa K. 2014. The role of dark septate endophytic fungal isolates in the accumulation of cesium by Chinese cabbage and tomato plants under contaminated environments. PLOS ONE. 9(10): e109233. doi: 10.1371/journal.pone.0109233.

Diop T. A., Wade T. K., Diallo A., Diouf M. \& Guage M. 2003. Solanum cultivars responses to arbuscular mycorrhizal fungi: growth and mineral status. Afr. J. Biotechnol. 2: 429-433.

Fracchia S., Aranda A., Gopar A., Silvani V., Fernandez L. \& GodeAs A. 2009. Mycorrhizal status of plant species in the Chaco Serrano Woodland from central Argentina. Mycorrhiza 19: 205-214.

Gashua I. B., Abba A. M. \& Gwayo G. A. 2015. Occurrence of arbuscular mycorrhizal fungi in chilli peppers (Capsicum 
annuum L.) grown in Sahelian soil. International Journal of Current Microbiology and Applied Sciences 4: 419-425.

Gianinazzi S., Gollotte A., Binet M.-N., van Tuinen D., Redecker D. \& WiPf D. 2010. Agroecology: the key role of arbuscular mycorrhizas in ecosystem services. Mycorrhiza 20: 519-530.

Halder M., Dhar P. P., Nandi N. C. \& Akhter S. 2015. Arbuscular Mycorrhizal colonization in some plant species and relationship with the soil properties in the BCSIR campus of Chittagong, Bangladesh. Research Journal of Biotechnology 10: 51-57.

Henry A. N., Kumari G. R. \& Chitra V. 1987. Flora of Tamil Nadu, India. 2. Botanical Survey of India, Coimbatore.

HePper C. M. 1984. Regulation of spore germination of the vesicular arbuscular mycorrhizal fungus Acaulospora laevis by soil pH. Trans. Brit. Mycol. Soc. 83: 154-156.

JACKSON M. L. 1971. Soil chemical analysis. Prentice Hall, New Delhi.

Jumpronen A. \& Trappe J. M. 1998. Dark septate endophytes a review of facultative biotrophic root-colonizing fungi. New Phytol. 140: 295-310.

Knapp S., Bohs L., Nee M. \& Spooner D. M. 2004. Solanaceae-A model for linking genomics with biodiversity. Comparative and Functional Genomics 5: 285-291.

Koske R. E. \& Gemma J. N. 1989. A modified procedure for staining roots to detect VA mycorrhizas. Mycol. Res. 92: 486-505.

LeE E.-H., Eo J.-K., Ka K.-H. \& Eom A.-H. 2013. Diversity of arbuscular mycorrhizal fungi and their roles in ecosystems. Mycobiology 41:121-125.

Li L., Li S.-M., Sun J.-H., Zhou L.-L., Bao X.-G., Zhang H.-G., \& ZHANG F.-S. 2007. Diversity enhances agricultural productivity via rhizosphere phosphorus facilitation on phosphorus-deficient soils. Proc. Natl. Acad. Sci. U.S.A. 104: 11192-11196.

Liu W., Zhang Y., Jiang S., Deng Y., Christie P., Murray P. J., Li X. \& Zhang J. 2016. Arbuscular mycorrhizal fungi in soil and roots respond differently to phosphorus inputs in an intensively managed calcareous agricultural soil. Scientific Reports 6: 24902; doi: 10.1038/srep24902.

Mandyam K. \& Jumpronen A. 2005. Seeking the elusive function of the root-colonising dark septate endophytic fungi. Stud. Mycol. 53: 173-189.

Manimegalai V., Selvaraj T. \& Ambikapathy V. 2011. Studies on isolation and identification of VAM fungi in Solanum viarum Dunal of medicinal plants. Advances in Applied Science Research 2: 621-628.

McGonigle T. P., Miller M. H., Evans D. G., Fairchild N. G. L. \& Swan J. A. 1990. A method which gives an objective measure of colonization of roots by vesiculararbuscular mycorrhizal fungi. New Phytol. 115: 495- 450.
Mohammad A. \& MitTra B. 2011. Effects of inoculation with stress adapted arbuscular mycorrhizal fungus Glomus deserticola on growth of Solanum melongena and Sorghum suclanse Staph. seedling under salinity and heavy metal stress conditions. Arch. Agron. Soil Sci. 59: 173-183.

Muthukumar T. \& TAMiLSELVI V. 2010. Occurrence and morphology of endorhizal fungi in crop species. Tropical and Subtropical Agroecosystems 12: 593-604.

Muthukumar T. \& Prakash S. 2009. Arbuscular mycorrhizal morphology in crops and associated weeds in tropical agroecosystems. Mycoscience 50: 233-239.

Muthukumar T., Senthilkumar M., Rajangam M. \& UdaIYAN K. 2006. Arbuscular mycorrhizal morphology and dark septate fungal associations in medicinal and aromatic plants of Western Ghats, Southern India. Mycorrhiza 17: 11-24.

Muthukumar T. \& UdAIYAN K. 2000. Arbuscular mycorrhizas of plants growing in the Western Ghats region, Southern India. Mycorrhiza 15: 297-313.

Muthukumar T. \& UdAIYAN K. 2002. Arbuscular mycorrhizae in cycads of southern India. Mycorrhiza 12: 213-217.

Muthuraja R., Muthukumar T., Sathiyadash K., Uma E., \& Priyadharsini P. 2014. Arbuscular mycorrhizal and dark septate endophyte fungal association in lycophytes and ferns of Kolli Hills, Eastern Ghats, Southern India. Amer. Fern J. 104: 67-102.

Narisawa K., Hambleton S. \& Currah R. S. 2007. Heteroconium chaetospira, a dark septate root endophyte allied to the Herpotrichiellaceae (Chaetothyriales) obtained from some forest soil samples using bait plants. Mycoscience 48: $274-281$.

Ragupathy S. \& Mahadevan A. 1993. Distribution of vesicular-arbuscular mycorrhizae in the in the plants and rhizosphere soils of the tropical plains, Tamil Nadu, India. Mycorrhiza 3:123-136.

Rajeshkumar P. P., Thomas G. V., Gupta A. \& Gopal M. 2015. Diversity, richness and degree of colonization of arbuscular mycorrhizal fungi in coconut cultivated along with intercrops in high productive zone of Kerala, India. Symbiosis 65: 125-141.

ReININGer V. \& Sieber T. N. 2013. Mitigation of antagonistic effects on plant growth due to root co-colonization by dark septate endophytes and ectomycorrhiza. Environmental Microbiology Reports 5: 892-898.

Ruotsalainen A. L., VÄre H. \& Vestberg M. 2002. Seasonality of root fungal colonization in low-alpine herbs. Mycorrhiza 12: 29-36.

Schultz P. A., Bever J. D. \& Morton J. B. 1999. A caulospora colossica sp. nov. from an ole field in Northe Carolina and morphological comparisons with similar species, A. laevis and A. koskei. Mycologia 9: 676-683.

Sekhara Reddy, D. M. R., Schorderet M., Feller U. \& ReInhardT D. 2007. A petunia mutant affected in 
intracellular accommodation and morphogenesis of arbuscular mycorrhizal fungi. Plant J. 51: 739-750.

Senés-Guerrero C., Torres-Cortés G., Pfeiffer S., Rojas M. \& SCHÜSSLER A. 2014. Potato-associated arbuscular mycorrhizal fungal communities in the Peruvian Andes. $M y$ corrhiza 24: 405-417.

Sengupta A., Chakraborty D. C. \& Chaudhuri S. 1989. Do septate endophytes also have a mycorrhizal function for plant under stress? In: A. MAHADEVAN, N. RAMAN \& K. NATARAJAn (eds), Mycorrhizae for Green Asia: Proceedings of the $1^{\text {st }}$ Asian Conference on Mycorrhizae, pp. 169-174. University of Madras, Madras, India.

Shamim D., Ahmed T. \& Ayub N. 1994. Influence of seasonal variations on VAM infection in perennial plants. Pakistan Journal of Plant Pathology 6: 77-80.

Sмith F. A. \& Sмith S. E. 1997. Transley review No 96. Structural diversity in (vesicular)-arbuscular mycorrhizal symbiosis. New Phytol. 137: 373-388.

Smith S. E. \& ReAd D. J. 2008. Mycorrhizal symbiosis. $3^{\text {rd }}$ ed. Academic Press, London.

Songachan L. S. \& Kayang H. 2012. Diversity and distribution of arbuscular mycorrhizal fungi in Solanum species growing in natural condition. Agricultural Research 1: 258-264.

Sun B., Zhang F., Zhou G., Chu G., Huang F., Wang Q., JIN L., LIN F. C. \& YANG J. 2013. Genetic variation in alkaloid accumulation in leaves of Nicotiana. J. Zhejiang Univ. (Nat. Sci. Ed.) 14: 1100-1109.

URCELAY C. 2002. Co-occurrence of three fungal root symbionts in Gaultheria poeppiggi DC. in Central Argentina. Mycorrhiza 12: 89-92.
Van Aarle I. M., Olsson P. A. \& SöDerström B. 2002. Arbuscular mycorrhizal fungi respond to the substrate $\mathrm{pH}$ of their extraradical mycelium by altered growth and root colonization. New Phytol. 155: 173-182.

VosÁtKa M. \& GRYNDLER M. 2000. Response of micropropagated potatoes transplanted to peat media to post-vitro inoculation with arbuscular mycorrhizal fungi and soil bacteria. Appl. Soil Ecol. 15: 145-152.

WANG B. \& QIU Y. L. 2006. Phylogenetic distribution and evolution of mycorrhiza in land plants. Mycorrhiza 16: 299-363.

WANG F. Y. \& SHI Z. Y. 2008. Biodiversity of arbuscular mycorrhizal fungi in China: a review. Advances in Environmental Biology 2: 31-39.

WANG M. \& JIANG P. 2015. Colonization and diversity of AM fungi by morphological analysis on medicinal plants in southeast China. The Scientific World Journal 2015(753842): 1-7. doi: 10.1155/2015/753842.

Xu W., Liu L., He T., Cao M., Sha L., Hu Y., Li Q. \& Li J. 2016. Soil properties drive a negative correlation between species diversity and genetic diversity in a tropical seasonal rainforest. Scientific Reports 6(20652) 1-8. doi: 10.1038/ srep20652.

Yao M. K., Tweddell R. J. \& Desilets H. 2002. Effect of two vesicular-arbuscular mycorrhizal fungi on the growth of micropropagated plantlets of potato and the extent of diseases caused by Rhizoctonia solani. Mycorrhiza 12: 235-242.

Zhang Y., Li T., Li F. \& Zhao Z.-W. 2011. The colonization of plants by dark septate endophytes (DSE) in the valley-type savanna of Yunnan, southwest China. African Journal of Microbiology Research 5: 5540-5547. 